\title{
Determination of Suitable Anti-Scaling Agent to Inhibit Scale Formation of Water Processed in Coal Power Plant System
}

\author{
Elvis Fosso-Kankeu*, Christopher.E. Brider, Johannes Redelinghuys, Gerhard Gericke, Nico Lemmer \\ and Frans Waanders
}

\begin{abstract}
Increasing pollution and scarcity of fresh water have prompted the need to develop and implement effective strategies to treat wastewater and reduce water usage. One such a strategy is to recirculate waste water in a power plant, but this strategy necessitates treatment. The considered water contains high levels of scale forming ions. Scale formation needs to be controlled, to practically increase the feasibility of recirculation processes. The selected test method to determine anti-scalant induction times is found to be inefficient and an improvement on the current method is proposed, and the possible causes for the inefficiency of the selected induction time test method highlighted. The main finding in this study was observed at $75^{\circ} \mathrm{C}$ as the anti-scalant PBTC performed better than ATMP; the former exhibiting longer induction time in reverse osmosis reject water.
\end{abstract}

Keywords-Anti-scalant, Scale, PBTC (2Phosphonobutane-1,2,4-Tricarboxylic Acid), AMTP (Amino Trimethylene Phosphonic Acid), Cooling water.

\section{INTRODUCTION}

Water is the single most important resource to sustain biological life. Due to the importance of water, the conservation thereof is becoming more significant. "The 2015/16 drought was the most severe in 23 years, leading to all South Africa's provinces, except Gauteng, being declared disaster areas" [1]. Coupled to that is the growing industrial pollution which put more pressure on the limited fresh water resource [2 - 17]. The high concentration of scale forming agents in such polluted water may pose significant problems when considering treatment through membrane or thermal technology. Scale build up in heat transfer units such as heat exchangers and membrane filters causes a decrease in the efficiency of heat transfer in a chemical or power plants cooling water system [18 - 20]. Maintenance to bring the

Manuscript received October 31, 2017. This project is supported by National Research Foundation (NRF), North-West University and Eskom Holdings Ltd.

Christopher E. Brider is currently studying post-grad degree at North-West University, Potchefstroom, South Africa (e-mail: chris.brider@gmail.com).

Elvis Fosso-Kankeu is with North-West University, Potchefstroom, South Africa. (e-mail: 24838616@nwu.ac.za).

Frans Waanders is with North-West University, Potchefstroom, South Africa.

Gerhard Gericke is currently an employee at the research department of Eskom Rosherville, South Africa, (e-mail: GerickG@eskom.co.za). equipment back up to working efficiency, needs to continuously be implemented and during maintenance, production could decrease and economic factors are negatively influenced. If membranes and other equipment work less efficiently due to scale build up during operation, more water is wasted which could have being used as supply for drinking water or any other necessary use.

The determining factors of water shortages, will not only be determined by current main causes such as droughts but will also be determined by increased population growth. [21] "The Water Research Commission (WRC) emphasized the need for water resource managers and planners to think outside the box for unconventional water sources, since water shortages stretch far beyond a drought. The South African legislation and regulation forbids industries around the country from discharging waste water in the environment without prior treatment. South African power plants can use the produced waste water more efficiently by recirculation thereof back into the cooling system.

The possible use of process units; which could form part of a cooling water reuse system such as the use of multi-effect distillator to produce water with a sufficient quality from a Reverse-osmosis (RO) reject effluent, encounters the problem of scaling (mostly due to calcium carbonate and calcium sulphate in solutions) which can affect heat exchange capacity [18]. Furthermore, scale formation on reverse osmosis membranes can significantly reduce the water flux through the membrane, necessitating frequent and costly maintenance. Scale forms due to changes in the physical conditions of the water. Anti-scaling agents work to inhibit this formation by interfering with the scale forming mechanism; by interfering with clustering, nucleation, crystal growth, or flocculation. Scaling ions form clusters, thereafter these clusters can grow into crystal structures. Many anti-scaling agent mechanisms have been proposed. One of the more general proposed mechanisms is that anti-scaling agents act to inhibit the onset of nucleation of scaling ions or by inhibiting the crystal growth. [22] propose two kinetic models by which anti-scaling inhibition takes place. Generally anti-scalants do not eliminate the scaling constituents or its tendency; instead they delay the onset crystallization (nucleation phase of crystallization) or retard the growth of mineral salt crystals (growth phase of 
crystallization) [22]. An example of an anti-scaling agent is polyaspartic acid, which is non-toxic, does not contain phosphorous and shows good biodegradability and the carboxylic, hydroxylic and acylamino functional groups in its chemical structure are what give this chemical its scale inhibiting properties, but does not show great inhibiting performance [23]. The functional groups having certain affinities to different scale forming substances.

By adding a suitable anti-scaling agent or a combination of more than one anti-scaling agent, the industry in turn could decrease maintenance costs on relevant equipment [26, 27]. A suitable method for determing anti-scalant induction time needs to be estabished and factors unaccounted for need to be taken into consideration while modifying the current method. Data from the current method of anti-scalant testing are analyzed and the possible cause of the failure of the method suggested.

\section{II.EXPERIMENTAL}

\section{A. Materials and Methods}

Sampling location was at Grootvlei coal fired power plant, where two water streams were sampled; cooling water blowdown/bleed off stream (CW-Blowdown), with a conductivity of $1.976 \mathrm{mS} / \mathrm{cm}$ and $\mathrm{pH} 7.4$ and RO-reject stream, with a conductivity of $1.076 \mathrm{mS} / \mathrm{cm}$ and $\mathrm{pH}$ 7.8. The water was stored in a fridge under a dark cover, eliminating light and decrease the chances of pre-mature precipitation of $\mathrm{CaCO}_{3}$. Samples were placed at room temperature for a day before use thereof.

A synthetic water sample (control) was prepared by dissolving salts with a concentration of $0.005 \mathrm{~mol} / \mathrm{dm}^{3} \mathrm{CaCl}_{2}$ and $0.005 \mathrm{~mol} / \mathrm{dm}^{3} \mathrm{Ca}(\mathrm{HCO} 3)_{2}$ in demineralized water. The $\mathrm{pH}$ of the control water was 7.5.

$500 \mathrm{~mL}$ of the $\mathrm{RO}$ reject and cooling water blowdown samples were spiked with $0.105 \mathrm{~g} \mathrm{Ca}\left(\mathrm{HCO}_{3}\right)_{2}$ and $0.138 \mathrm{~g}$ $\mathrm{CaCl}_{2}$; amounting to the same content as the control solution. The synthetic control sample was used to investigate the difference between the sampled water (CW-blowdown and RO-reject), and the synthetic water sample and to note if the minerals in the sampled water interacts with the scale forming mechanism in any way.

\section{B. ICP-OES Analysis}

An ICP analysis using ICP Expert II, Agilent Technologies 720 ICP-OES (Agilent Technologies, USA) was performed to determine the concentration of calcium present in the two sampled waters.

\section{EDTA Titration}

Establishment of the amount of total hardness (sum of magnesium and calcium hardness as $\mathrm{CaCO}_{3}$ ) and calcium hardness as $\mathrm{CaCO}_{3}$ was achieved by an EDTA titration.

\section{Static Induction Test}

A static induction test was performed in order to determine the induction time of two anti-scalants. PBTC (2-
Phosphonobutane-1,2,4-Tricarboxylic Acid) and AMTP (Amino Trimethylene Phosphonic Acid)

Anti-scalants were dosed into both samples, including the control solution. The anti-scalants were evaluated at temperatures of $25^{\circ} \mathrm{C}, 40^{\circ} \mathrm{C}$ and $75^{\circ} \mathrm{C}$.

A dosage concentration of anti-scalant was selected by using a modelling program (French Creek Software ${ }^{\circledR}$ ). After experimentation of the modeled dosage, final dosages of 0.2 ppm of PBTC and ATMP were chosen for the RO-reject sample and $0.1 \mathrm{ppm}$ of PBTC and ATMP was chosen for the cooling water blowdown sample as well as a control solution, as these dosages showed a drop in conductivity within a reasonable time. $\mathrm{RO}$-reject and $\mathrm{CW}$-blowdown were spiked with $0.005 \mathrm{~mol} / \mathrm{dm}^{3} \mathrm{CaCl}_{2}$ and $0.005 \mathrm{~mol} / \mathrm{dm}^{3} \mathrm{Ca}\left(\mathrm{HCO}_{3}\right)_{2}$

An Arduino Uno micro-controller was used to measure the resistivity of the samples over time by means of a voltage divider calculation:

$$
R_{\text {water }}=\frac{V_{\text {out }} R_{1}}{V_{s}-V_{\text {out }}}
$$

Where $R_{\text {water }}$ is the resistivity of the water, $V_{\text {out }}$ is the resistivity of the voltage read at the sensor and $V_{s}$ is the output voltage of the source (Arduino). $V_{s}$ is $5 \mathrm{~V}$, with $\mathrm{R}_{1}$ a chosen voltage of $1740 \Omega$. The resistance is chosen such that the sensor voltage can stay within the range of $0-5 \mathrm{~V}$.

Two copper wires were placed in the water samples. Stirring was achieved by using a jar test stirrer, which stirs the solution at $60 \mathrm{rpm}$. Six jars, containing $500 \mathrm{~mL}$ each of the water samples were tested simultaneously, consisting of two blank samples, two ATMP dosed samples and two PBTC dosed samples. The samples were heated up by means of circulating hot water on a tray containing the six jars.

The measured resistivity was converted to conductivity, where data was then treated with a Savitzky-Golay smoothing algorithm, to eliminate noise from the data.

\section{RESULTS AND DISCUSSION}

\section{A. Sample Pre-Analysis}

The calcium content of the samples determined using ICPOES was $83.61 \mathrm{ppm}$ in the CW-Blowdown sample and 170.4 ppm in the RO-reject sample.

An EDTA titration resulted in a total hardness as $\mathrm{CaCO}_{3}$ of $275.08 \mathrm{mg} \mathrm{CaCO}_{3} / \mathrm{L}$, of which the Calcium hardness was determined as $160.46 \mathrm{mg} \mathrm{CaCO}_{3} / \mathrm{L}$, for the $\mathrm{CW}$-Blowdown sample, whereas the RO-reject sample contained $558 \mathrm{mg}$ $\mathrm{CaCO}_{3} / \mathrm{L}$, of which the Calcium hardness was $348 \mathrm{mg}$ $\mathrm{CaCO}_{3} / \mathrm{L}$

\section{B. Static Induction Test at $25^{\circ} \mathrm{C}$}

Note: Conductivities are not accurate due to noise, polarization on the wire probes and electro-magnetic induction present from the use of an Arduino set-up, the changes in conductivity can however be considered for determining an induction time in the case of this experiment. 
Anti-scalants (PBTC \& ATMP) were evaluated at $25^{\circ} \mathrm{C}$. The first gradual increase in conductivity was due to the increase of energy in the form of heat, as the samples were heated from ambient temperature to $25^{\circ} \mathrm{C}$ in this case. Ions moved more readily upon elevated temperature, thereby increasing conductivity. A decrease in conductivity occurs when the ion content of the water decrease, which is the case when scale precipitates/depositions from the water. Experimental runs of 12 hours were considered for $25^{\circ} \mathrm{C}, 6$ hours for $40^{\circ} \mathrm{C}$ and 2 hours for $75^{\circ} \mathrm{C}$

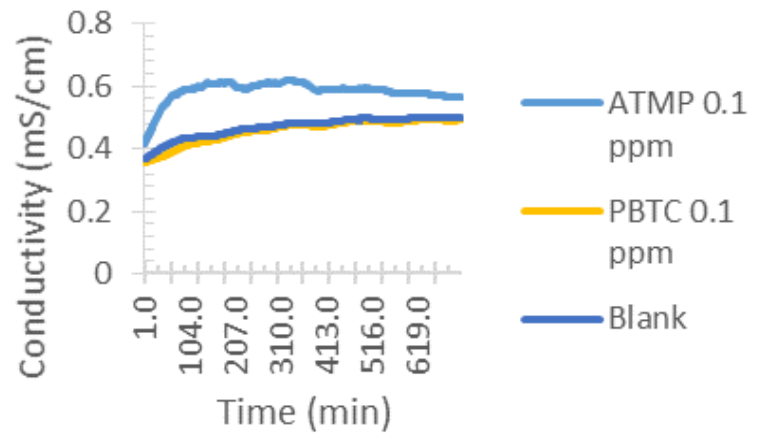

Fig 1: Conductivity over time (Control solution $\left.25^{\circ} \mathrm{C}\right)$



Fig 2: Conductivity over time $\left(\mathrm{CW}\right.$ sample $\left.25^{\circ} \mathrm{C}\right)$

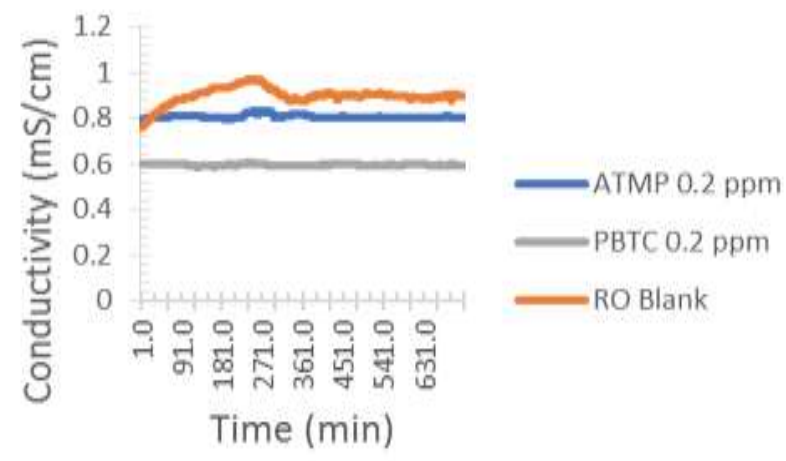

Fig 3: Conductivity over time (RO sample $\left.25^{\circ} \mathrm{C}\right)$

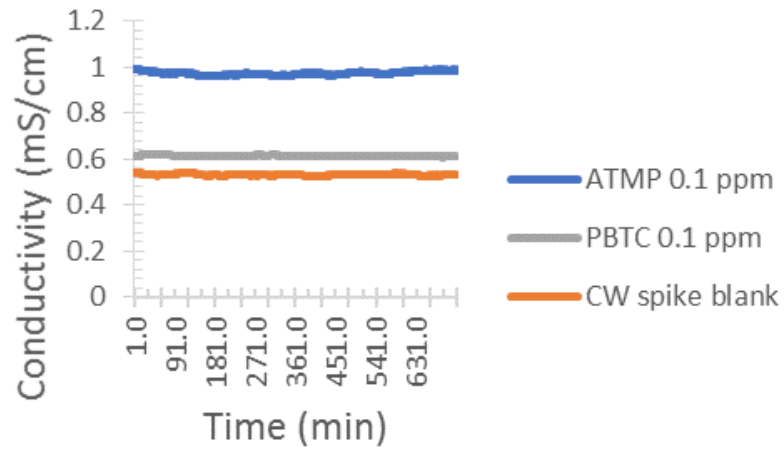

Fig 4: Conductivity over time (CW spike sample $25^{\circ} \mathrm{C}$ )

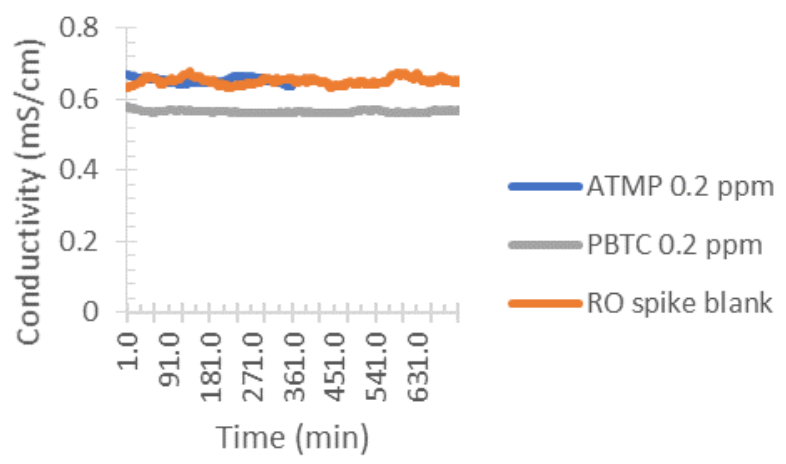

Fig 5: Conductivity over time ( $\mathrm{RO}$ spike sample $25^{\circ} \mathrm{C}$ )

As can be seen from Figures 1-5, there was no significant change in conductivity for any of the considered samples at room temperature. At room temperature conditions and for the time considered, the samples are under saturated with potential scale forming ions $\left(\mathrm{Ca}^{2+}\right.$ and $\left.\mathrm{CO}_{3}{ }^{2-}\right)$.

\section{Static induction test at $40^{\circ} \mathrm{C}$}

The initial increase in conductivity observed at $40^{\circ} \mathrm{C}$ was higher than that noticed at $25^{\circ} \mathrm{C}$. The effect of temperature on conductivity, was therefore observed.

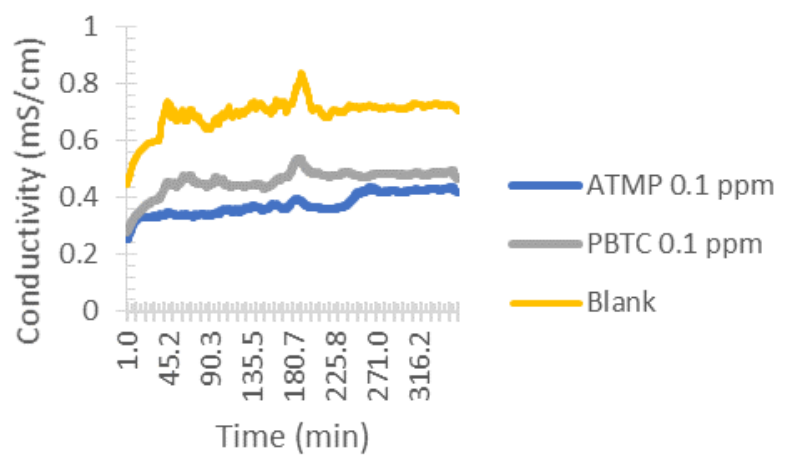

Fig 6: Conductivity over time (Control solution $40^{\circ} \mathrm{C}$ ) 


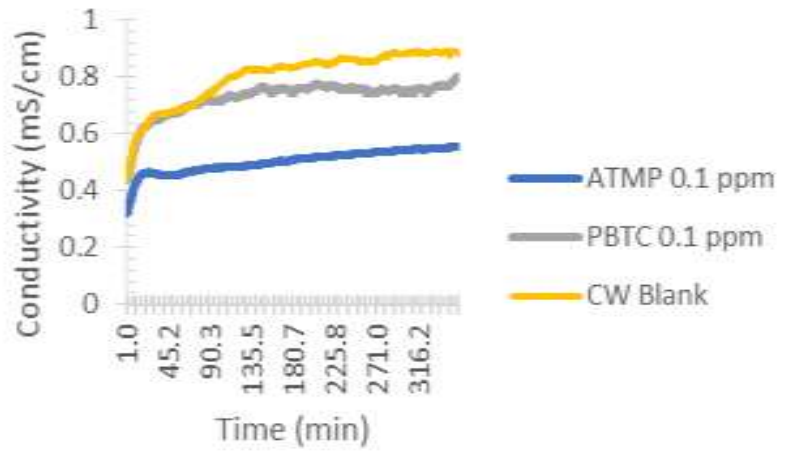

Fig 7: Conductivity over time (CW sample $\left.40^{\circ} \mathrm{C}\right)$

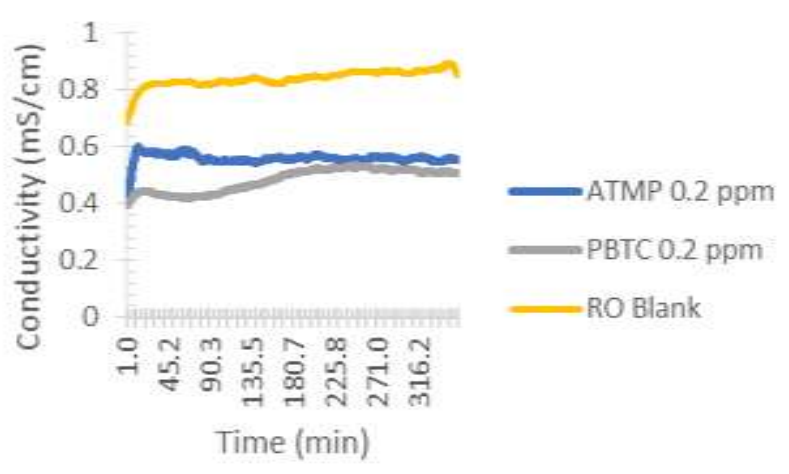

Fig 8: Conductivity over time (RO sample $\left.40^{\circ} \mathrm{C}\right)$

In Fig 7 and Fig 8 it seems that the rate of change in conductivity decreases during the initial increase in temperature of the water, which could be indicative of the occurrence of precipitation, which could be the case for Fig 7as this behavior occurs on the Blank sample, but for Fig 8 the behavior occurs in the PBTC dosed sample and not in the blank sample, which is inconsistent and counter intuitive to the idea that anti-scalants increase induction time.

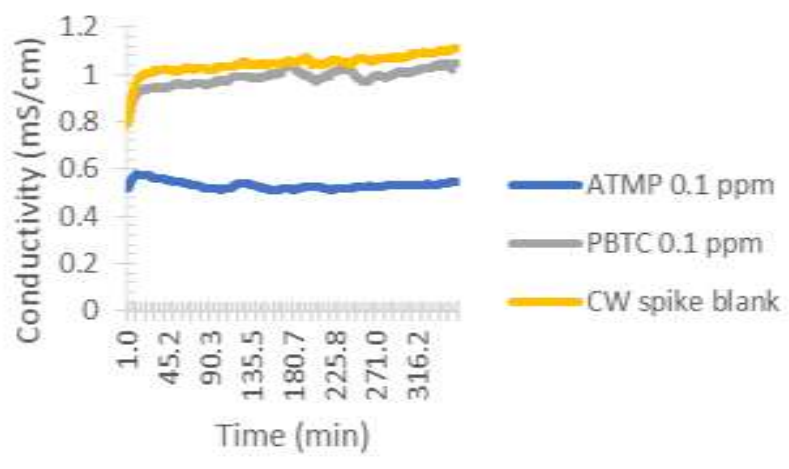

Fig 9: Conductivity over time (CW spike sample $\left.40^{\circ} \mathrm{C}\right)$

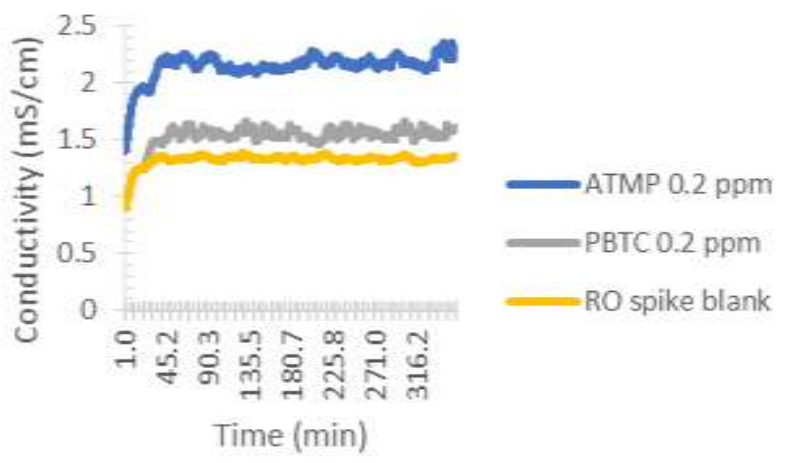

Fig 10: Conductivity over time (RO spike sample $40^{\circ} \mathrm{C}$ )

At $40^{\circ} \mathrm{C}$, there is no observable change in conductivity, and giving rise to the same situation as for $25^{\circ} \mathrm{C}$, the control solution and samples are both below super saturation at $40^{\circ} \mathrm{C}$ to undergo precipitation of $\mathrm{CaCO}_{3}$.

A graph obtained from the French Creek Modelling application, MineSat ${ }^{\mathrm{TM}}$; reveals that the degree of supersaturation for the $\mathrm{CW}$-blowdown and RO-reject stream is relatively low at a temperature of $40^{\circ} \mathrm{C}$ and a $\mathrm{pH} 7.4$ for $\mathrm{CW}$ Blowdown and $\mathrm{pH}$ of 7.8 for RO-reject (Note: the color coding is from Blue which is good to red which is bad and the color can be noted in Fig 11 and Fig 12)

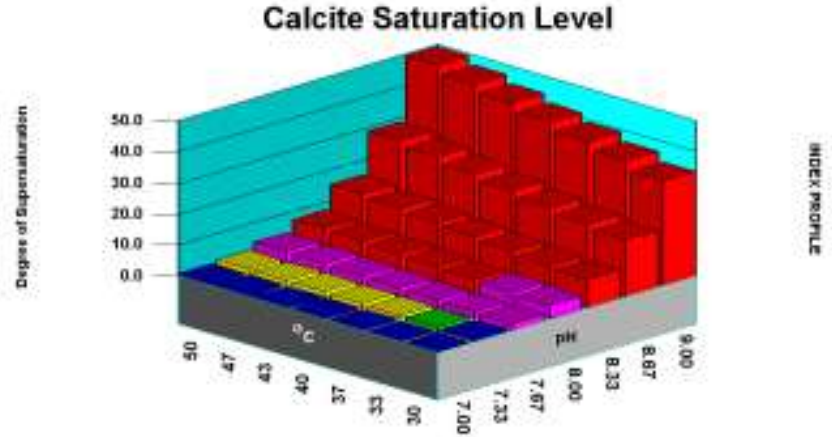

Fig 11: French creek modelling for CW-blowdown sample. Adapted from: French Creek software's MineSat ${ }^{\mathrm{TM}}$ [24]

Calcite Saturation Level

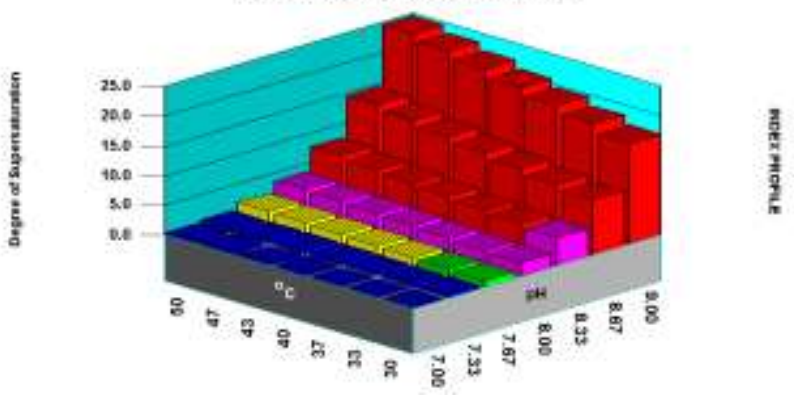

Fig 12: French creek modelling for RO-reject sample. Adapted from: French Creek software's MineSat ${ }^{\mathrm{TM}}$ [24]

D. Static induction test at $75^{\circ} \mathrm{C}$

Experimental induction tests on the samples and solutions at $75^{\circ} \mathrm{C}$ produced a diversity of results. 


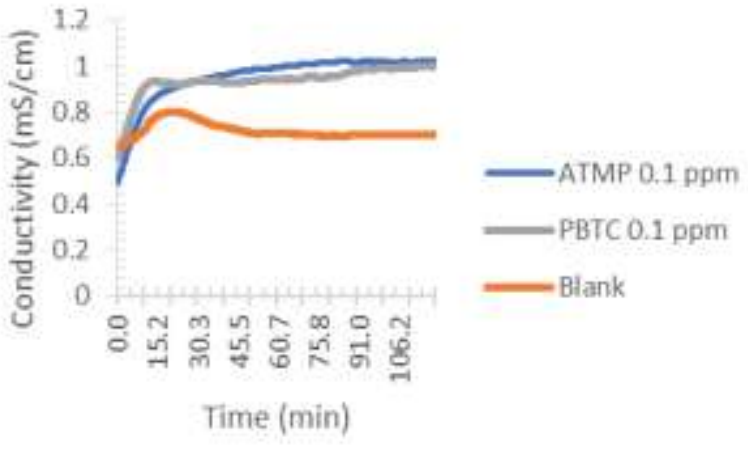

Fig 13: Conductivity over time (Control solution $75^{\circ} \mathrm{C}$ )

As seen in Fig 13 ATMP performed better than PBTC in terms of induction time for the control solution, as no drop in conductivity occurs for ATMP. The sample containing PBTC shows a very slight decrease in conductivity at $21 \mathrm{~min}$, whereas the decrease in conductivity of the blank is slightly steeper starting at $25 \mathrm{~min}$. The slight decrease in conductivity could be an indication of the occurrence of precipitation, but the drop is not large enough to draw a solid conclusion.

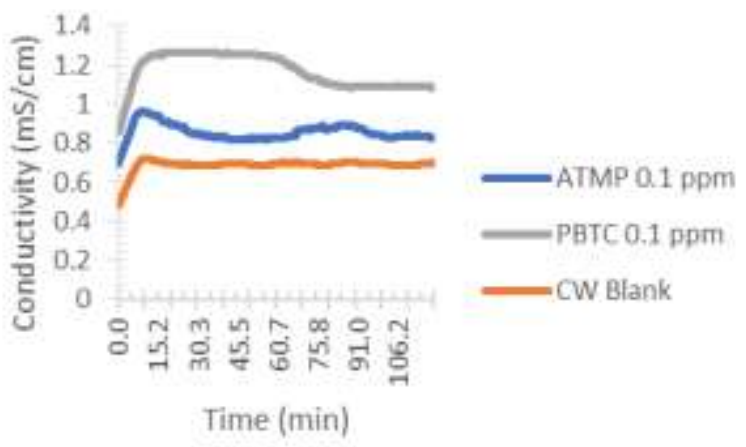

Fig 14: Conductivity over time $\left(\mathrm{CW}\right.$ sample $\left.75^{\circ} \mathrm{C}\right)$

In the case of the CW-Blowdown sample (Fig 14 and Fig 15), it appears that PBTC performs better than ATMP as the conductivity drops much later (62 mins) than that of the ATMP sample (12 mins), while an earlier drop (10 mins) was recorded for the control sample after which the conductivity remained constant for the rest of experiment; it could however be noted that there is no significant difference between the trend observed in the presence of ATMP and the one observed in the control sample.

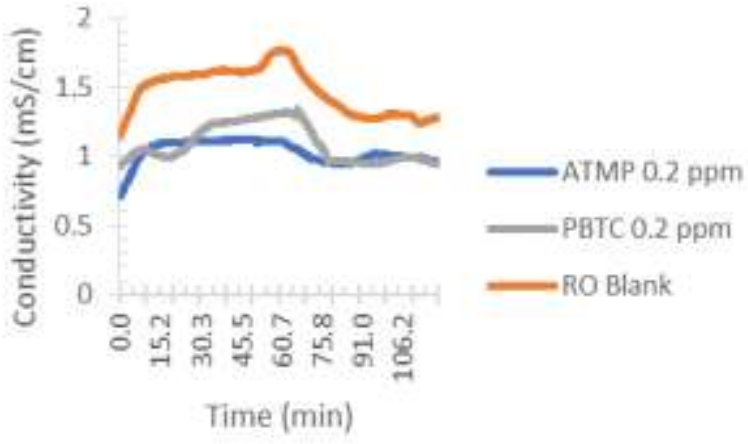

Fig 15: Conductivity over time (RO sample $\left.75^{\circ} \mathrm{C}\right)$
For the RO-reject sample (Fig 15), conductivity appears to decrease before a temperature of $75^{\circ} \mathrm{C}$ is reached. At high temperatures scaling becomes significant. It can be observed on Figure 15 that all the major drops in conductivity are recorded almost at the same time, although a slight delay by the PBTC could also be identified.

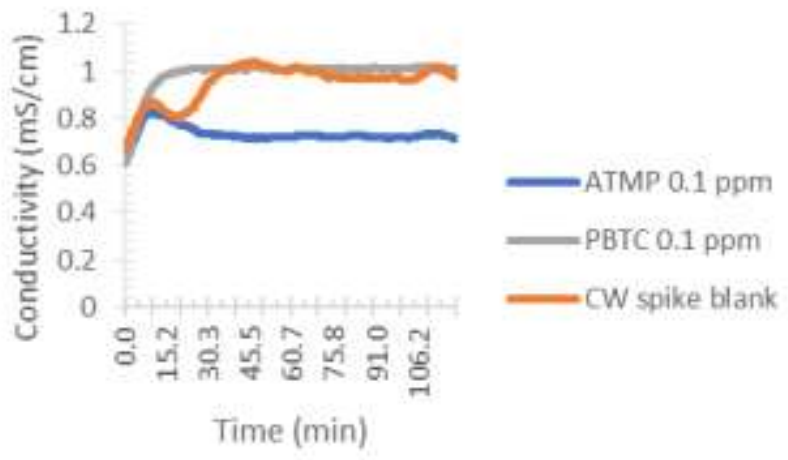

Fig 16: Conductivity over time (CW spike sample $75^{\circ} \mathrm{C}$ )

In Fig 16 the Blank CW spiked solution shows precipitation at $62^{\circ} \mathrm{C}$ and 11 mins. ATMP starts a drop in conductivity at $60^{\circ} \mathrm{C}$ and 12 mins, whereas PBTC shows no drop in conductivity throughout, hence no signs of precipitation.

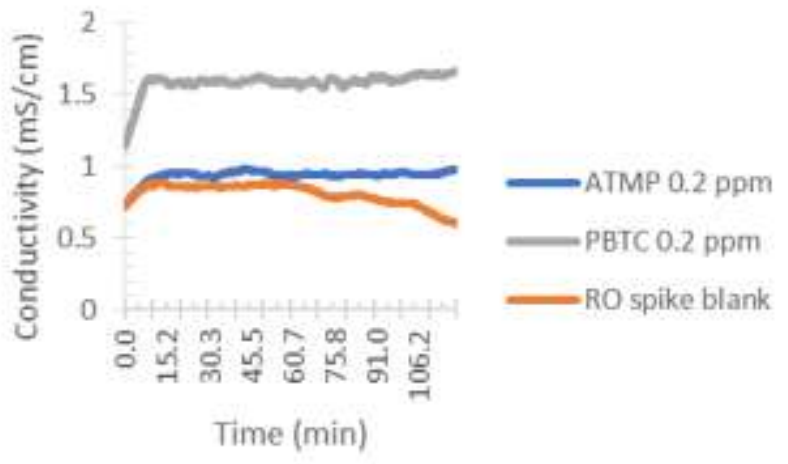

Fig 17: Conductivity over time (RO spike sample $\left.75^{\circ} \mathrm{C}\right)$

The spiked RO-reject sample showed no signs of drop in conductivity fort the two considered anti-scalant dosed samples. The blank spiked RO-reject sample started a drop in conductivity at 65 mins.

\section{E. General Discussion}

Increasing the rate of heat transfer could allow the prediction of the performance of anti-scalants within reasonable time, as precipitation may be occurring before reaching the targeted temperature. Accurate evaluation of the performance of anti-scalants could be achieved by designing a system that will shorten the heating time required to reach the targeted temperature as in the case on this study precipitation occurred during the heating process, affecting proper evaluation of the performance of anti-scalants. 


\section{IMPROVEMENTS}

\section{A. Improvement of Testing Method}

An improved method of testing the anti-scalants is proposed whereby, a closed jar cylinder is used in place of an open jar. A closed jar can better aid in controlling the temperature and pressure while keeping the contents constant, by overcoming excessive evaporation of water. An accurate and reliable measuring device should be used and more variables should be taken into consideration, such as $\mathrm{pH}$, which can allow to monitor the behaviour of critical elements or compounds in solution such as bicarbonate, carbonate and carbon dioxide content.

\section{V.CONCLUSION}

At $25^{\circ} \mathrm{C}$ there is hardly any change in conditions when temperature of the sample is changed from ambient temperature to $25^{\circ} \mathrm{C}$. Conductivity remains constant for all samples, which indicates that the samples are below supersaturated conditions.

After temperatures are reached at $40^{\circ} \mathrm{C}$, conductivities remain fairly constant for all samples.

Increasing the temperature to $75^{\circ} \mathrm{C}$ shows a diversity of trends. In some cases conductivity drops during the initial temperature increase phase, while in others a drop in conductivity was observed only when the targeted temperature was reached. However, in general the anti-scalant PBTC performed better than ATMP both for RO reject water and CW. Overall, it is important to note that in the context of laboratory study aiming to compare the performance of antiscalants, one must ensure that the solutions considered are supersaturated if results are to be obtained in a short time.

\section{ACKNOWLEDGEMENTS}

The authors are grateful to the sponsor from the North-West University and the National Research Foundation in South Africa. Any opinion, findings and conclusions or recommendations expressed in this material are those of the authors and therefore the NRF does not accept any liability in regard thereto.

\section{REFERENCES}

[1] M. Zhuwakinyu, "Water 2016: a review of South Africa's water sector", Johannesburg, South Africa: Creamer Media's Research Channel Africa, 2016.

[2] E. Fosso-Kankeu, AF Mulaba-Bafubiandi, BB Mamba and TG Barnard. 2011. Prediction of metal-adsorption behaviour in the remediation of water contamination using indigenous microorganisms. Journal of Environmental Management, 92 (10), pp 2786-2793.

[3] H. Mittal, E. Fosso-Kankeu, Shivani B. Mishra, Ajay K. Mishra. 2013. Biosorption potential of Gum ghatti-g-poly (acrylic acid) and susceptibility to biodegradation by B. subtilis. International Journal of Biological Macromolecules. 62: 370-378.

[4] E. Fosso-Kankeu, AF Mulaba-Bafubiandi. 2014. Implication of plants and microbial metalloproteins in the bioremediation of polluted waters. Journal of Physics and Chemistry of the Earth. 67-69: 242-252.

[5] E. Fosso-Kankeu, AF Mulaba-Bafubiandi. 2014. Challenges in the escalation of metal-biosorbing processes for water treatment: applied and commercialized technologies. African Journal of Biotechnology. 13(17): 1756-1771.

[6] E. Fosso-Kankeu, H. Mittal, S.B. Mishra, A.K. Mishra. 2015. Gum ghatti and acrylic acid based biodegradable hydrogels for the effective adsorption of cationic dyes. Journal of Industrial and Engineering Chemistry. 22: 171-178.

[7] E. Fosso-Kankeu, H. Mittal, F. Waanders, I.O. Ntwampe, S.S. Ray. 2016. Preparation and characterization of gum karaya hydrogel nanocomposite flocculant for metal ions removal from mine effluents. International Journal of Environmental Science and Technology. 13: 711-724.

[8] E. Fosso-Kankeu, F. Waanders, E. Maloy. 2016. Copolymerization of ethyl acrylate onto guar gum for the adsorption of $\mathrm{Mg}$ (II) and $\mathrm{Ca}$ (II) ions. Desalination and Water Treatment. doi: 10.1080/19443994.2016.1165147: 1-10.

[9] E. Fosso-Kankeu, F. Waanders, C.L. Fourie. 2016. Adsorption of Congo Red by surfactant-impregnated bentonite clay. Desalination and Water Treatment. doi: 10.1080/19443994.2016.1177599: 1-9.

[10] E. Fosso-Kankeu, A.F. Mulaba-Bafubiandi, L.A. Piater, M.G. Tlou. 2016. Cloning of the cnr operon into a strain of Bacillaceae bacterium for the development of a suitable biosorbent. World Journal of Microbiology and Biotechnology. DOI 10.1007/s11274-016-2069-5.

[11] E Fosso-Kankeu, A Webster, IO Ntwampe, FB Waanders. 2016. Coagulation/flocculation potential of polyaluminium chloride and bentonite clay tested in the removal of methyl red and crystal violet. Arabian Journal for Science and Engineering. DOI 10.1007/s13369016-2244-x

[12] E. Fosso-Kankeu, Hemant Mittal, S. Marx and Suprakas Sinha Ray. 2016. Hydrogel-based bioflocculants for the removal of organic pollutants from biodiesel wastewater. Journal of Polymer and Environment. DOI 10.1007/s10924-016-0870-8.

[13] Elvis Fosso-Kankeu, Frans Waanders, Maryka Geldenhuys. 2016. Impact of nanoparticles shape and dye property on the photocatalytic degradation activity of $\mathrm{TiO} 2$. International Journal of Science and Research. 5 (11): 528 - 535.

[14] Elvis Fosso-Kankeu, Alusani Manyatshe, Frans Waanders. 2017. Mobility potential of metals in acid mine drainage occurring in the Highveld area of Mpumalanga Province in South Africa: Implication of sediments and efflorescent crusts. International Biodeterioration and Biodegradation. 119: 661-670.

[15] Elvis Fosso-Kankeu, Hemant Mittal, Frans Waanders, Suprakas Sinha Ray. 2017. Thermodynamic properties and adsorption behaviour of hydrogel nanocomposites for cadmium removal from mine effluents. Journal of Industrial and Engineering Chemistry. 48: 151-161.

[16] Elvis Fosso-Kankeu, Frans B. Waanders, Frederik W. Steyn. 2017. Removal of $\mathrm{Cr}(\mathrm{VI})$ and $\mathrm{Zn}$ (II) from an aqueous solution using an organic-inorganic composite of bentonite-biochar-hematite. Desalination and Water Treatment. 59: 144-153.

[17] A. Manyatshe, E. Fosso-Kankeu, D. van der Berg, N. Lemmer, F. Waanders, H. Tutu. 2017. Dispersion of inorganic contaminants in surface water in the vicinity of Potchefstroom. Physics and Chemistry of the Earth. 100: 86-93.

[18] Fosso-Kankeu E, Redelinghuys J, Waanders F, Rogers D, Bruinsma D, Gericke G. 2016. Determination of water evaporation rate in an assembled bench scale MED and impact of anti-scaling agents on the morphology of scale. International Conference on Advances in Science, Engineering, Technology and Natural Resources (ICASETNR-16) Nov. 24-25, 2016, Parys - South Africa. ISBN: 978-93-84468-79-8.

[19] Fosso-Kankeu E, Waanders F, Van Niekerk D, Rogers D, Gericke D. 2016. Treatment of raw and processed waters from coal power plant using $\mathrm{PACl}$ supplemented with cationic organic polymer and bentonite. International Conference on Advances in Science, Engineering, Technology and Natural Resources (ICASETNR-16) Nov. 24-25, 2016, Parys - South Africa. ISBN: 978-93-84468-79-8.

[20] Fosso-Kankeu E, Waanders F, Swiegers R, Ntwampe IO, Rogers D, Gericke G. 2016. Impact of the physico-chemical properties of water on the flocculation performance of lime, clay and other polymers. International Conference on Advances in Science, Engineering, Technology and Natural Resources (ICASETNR-16) Nov. 24-25, 2016, Parys - South Africa. ISBN: 978-93-84468-79-8.

[21] C. Landie, South Africa's water supply status. Water \& Sanitation Africa, (3), 2016. pp.58-60. 
[22] Y.M. Al-Roomi, and K.F. Hussain, Potential kinetic model for scaling and scale inhibition mechanism. Desalination, 2016, 393, pp.186-195.

[23] Y. Zhang, H. Yin, Q. Zhang, Y. Li, and P. Yao. Synthesis and characterization of novel polyaspartic acid/urea graft copolymer with acylamino group and its scale inhibition performance. Desalination, 2016, 395, pp.92-98.

[24] R. Ferguson,. MineSAT - Mining, Process Water Modeling, Chemistry \& Treatment. [online] Frenchcreeksoftware.com. 2017, Available at: http://www.frenchcreeksoftware.com/MineSAT/ [Accessed 29 Oct. 2017].

[25] K. Demadis, and A. Ketsetzi,. Degradation of Phosphonate-Based Scale Inhibitor Additives in the Presence of Oxidizing Biocides: "Collateral Damages" in Industrial Water Systems. Separation Science and Technology, 2007, 42(7), pp.1639-1649.

[26] L. Huchler. Update your industrial water treatment operations. Hydrocarbon Processing, 2008, 87(12), pp.83-83.

[27] H. Väisänen, $\mathrm{CaCO} 3$ Scale inhibition in paper making processesEvaluation of testing methods and inhibitor performance, 2011, Undergraduate. Tampere University of Technology.

The corresponding author is currently an Associate Professor in the School of Chemical and Minerals Engineering at the North-West University (Potchefstroom). He is an NRF rated researcher who has published journal articles, book chapters and book.

Prof Elvis Fosso-Kankeu has been the recipient of several merit awards. 